\title{
The Problems Analysis of College Students' Post Practice Management Wang Dongqiang ${ }^{1, a}$ and Tian Shuqin ${ }^{2,} b^{*}$ \\ 1. Chongqing University of Arts and Sciences, Chongqing, China, 402160 \\ 2. Chongqing University of Arts and Sciences, Chongqing, China, 402160 \\ acqwdq2011@163.com, btianshuqin99@126.com \\ * The corresponding author
}

Keywords: College; Students' post practice; Management dilemma; Basic thinking

\begin{abstract}
There are still weak links in the quality control of college students'post practice , especially in the absence of decentralized practice monitoring, which seriously affects the quality of personnel training. In the light of the various difficulties existing in the management of college students' post practice, it is of great theoretical and practical significance to strengthen the management of college students' post practice. The basic ideas of strengthening the management of post practice include: strengthening the centralized management of college students'post practice; perfecting the linkage mechanism of college students'post practice management; developing college students' post practice management service system; and establishing the large data integration system of college students'post practice. In the future, the development trend of college students' post practice management of college students will be to deepen the reform of government purchase service mode.
\end{abstract}

\section{Introduction}

In April 2016, the Ministry of Education, the Ministry of Finance, the Ministry of Human Resources and Social Security, the General Administration of State Security Supervision and Supervision, and the China Insurance Regulatory Commission (CIRC) formulated the Regulations on the Management of Students' Practice in Vocational Schools (Department of vocational education and adult education, Ministry of Education[2016] No. 3) to standardize the work of students' practice in vocational schools, safeguard the legitimate rights and interests of students, schools and practice units, and provide policy basis improve for the quality of technical skills training. In order to thoroughly implement the spirit of the national medium and long-term education program, technical and technical colleges and applied undergraduate colleges have implemented the concept of "application-oriented" development, and have formed a "student-centered, demand-oriented, industry-based, cooperation-based platform, quality-centered" training system with characteristic. Under the guidance of this personnel training system, schools attach great importance to the construction of post practice platform, set up school-enterprise cooperative training classes, set up practice bases with enterprises and institutions, and strengthen students' post practice by means of integration of production and teaching and school-enterprise cooperation. We should vigorously carry out the inspection and guidance work in the internship links and adopt the "three-in-one" inspection method, namely, the combination of self-examination of secondary colleges and departments with spot checks of schools, the combination of on-campus inspection with off-campus visits, the combination of questionnaire survey and on-the-spot checks, mainly through telephone spot checks, with emphasis on the inspection of teachers'guidance and students' practice. In order to ensure the smooth development of internship work and the quality of internship, the spot check situation is recorded in detail and fed back to the relevant colleges in time. However, there are still weak links in the quality control of post practice, especially in the decentralized practice, which seriously affects the quality of personnel training.

\section{The Main Problems of College Students' Post Practice Management}

The author relies on the key projects of Chongqing's higher education teaching reform, such as 
"Innovation and Exploration of College Student post practice Management under the Mode of Government Purchase Service" and "Development and Practice of College post practice Management Integrated System under the Age of Big Data", to understand and grasp the basic connotation and significance of college students' post practice by using the method of literature research. On the basis of the main functions, through field observation, in-depth interviews, case analysis and other research methods, this paper reveals that the practical dilemma faced by college students' post practice is mainly manifested in the following aspects:

Firstly, generally speaking, the graduation practice of teachers' education major students mainly focuses on centralized practice, which is convenient for centralized management. Non-teacher educational practice bases are scattered, and each base receives a limited number of interns every year. It is difficult for schools to send people to practice guidance and process monitoring.

Secondly, from the perspective of teacher guidance, the responsibilities and fees of outside-school instructors have not been put in place; part-time instructors'dispatch, working hours and working expenses have been clearly stipulated, but they need to be effectively implemented.

Thirdly, from the perspective of practice management, the number of students concentrating on practice is limited, and the students are mainly distributed practice. Although some colleges use micro-mail, micro-blog, QQ, mailbox, telephone and other process management, they have not been able to monitor and manage the whole staff and the whole process.

Fourthly, the self-built basic status database of on-the-job practice can not be linked and integrated with the systems of administration, student management, teachers and funds, so it is difficult to form effective large-scale data management with aggregated data in time.

\section{The Main Significance of Strengthening College Students' Post Practice Management}

Faced with the various "chaos" and management difficulties existing in the post practice of college students, strengthening the management of post practice of college students has a strong theoretical value and practical significance.

From a macroscopic point of view, in view of the phenomenon of "shaving head and picking head" in the process of promoting college students' post practice through school-enterprise cooperation, the problem of "college hot and enterprise cold" can be solved to a certain extent by strengthening the management of college students' post practice.

From the middle point of view, this paper discusses the necessity, feasibility and urgency of strengthening the management of college students' on-the-job practice in view of various defects and practical difficulties in the current management mode of college students' on-the-job practice.

From the microcosmic point of view, in view of some chaotic phenomena in process of the college students' post practice, to a certain extent, alleviate or solve the lackness of effective supervision at the level of the government; the unified "arranged" and "sheep" management at the university level; the post practice fees "power rent-seeking" and the assessment of "water release" problems; the internship students exist at the level of the post practice. There are some problems, such as the disequivalence of specialties, the absence of "on-the-job" and "low-cost labor force", and the lackness of motivation for enterprises to participate in the post practice system for college students.

\section{The Basic Thinking of Strengthening College Students' Post Practice Management}

\section{Strengthening Centralized Management of Post Practice}

Efforts should be made to strengthen the construction of non teacher education practice bases and increase the proportion of centralized practice. For the interns in the centralized practice base, we should employ teachers from industry and enterprise for guidance and management, and implement the fee for guidance of instructors; at the same time, we should send professional teachers to practice guidance and management, or send professional staff for itinerant guidance and inspection and supervision. Measures should be taken to strengthen the decentralized practice monitoring of non-teacher education majors. The process management of decentralized practice students should 
be strengthened by means of micro-letters, micro-blogs, short messages, QQ and e-mail, and the work process records and the acceptance of practice results should be strengthened.

\section{Improve the Linkage Mechanism of Post Practice Management}

We should further strengthen the effective linkage among the teaching, learning and engineering departments and the secondary colleges, especially between the secondary colleges and the practice units, and give full play to the role of the teaching management team, the learning and engineering teams and the instructors of the practice units in the post practice management. Under the background of new practice management mode, to perfect the evaluation mechanism of students' post practice inspection, school counselors (or graduate thesis instructors) and practice unit instructors should conduct a comprehensive assessment of graduates from the aspects of students' theoretical knowledge, professional and technical abilities and comprehensive professional quality.

\section{Develop Post Practice Management Service System}

The post practice service management system based on the cooperation among schools, students and practice units can improve the practice management and service level. The system should be able to meet the requirements of graduate practice management and personnel training from the aspects of informationization management of practice affairs, effective monitoring of students'practice (mainly using GPS information of students' mobile phones to locate and sign in), unified management of practice units, and statistics of relevant practice data. For students, the system can meet the needs of students' employment and personalized development from the aspects of student practice affairs, student practice remote check-in, check important notice and recruitment information, timely communication and exchange anmong student, practice tutor, and counselor.For the practice unit, the system can publish recruitment information and record students' practice process.

\section{Establish Large Data Data Integration System of Post Practice}

We should break through the system barriers and establish large data integration system, solve the problem of information isolated island, connect teaching management, human resource management, student comprehensive service management, scientific research and discipline construction management, resource management, quality management, decision-making services and other systems to form unique source of data integration system shared by the whole school. We should give full play to the normal monitoring function of teaching basic state database and improve the quality of post practice of college students in an all-round way.

\section{Conclusion}

Faced with the problems existing in the post practice of College students, it is urgent to strengthen the management of post practice of college students. It is necessary to make a comprehensive comparative study on the typical mode of post practice management of college students from the aspects of main connotation, advantages and disadvantages, implementation principles, applicable conditions, difficulties and obstacles, and cooperation mechanism. We should put forward the mutual cooperation mechanism and guarantee system of government purchasing service in the post practice management of college students from of government investment and recognition mechanism of study base, cost sharing and compensation mechanism of students' post practice, tax preferential mechanism of government for enterprises accepting internship, service purchasing mechanism of industry practice standards, joint participation mechanism of schools and enterprises accredited by post practice assessment, double----tutor system of post practice management and quality control of practice social participation mechanism and organization, resource allocation, management team, fund guarantee, practice base, etc. , so as to mobilize the government, enterprises, schools, students and social organizations. The enthusiasm and initiative of participating in personnel training can produce good social benefits. It can not only effectively enhance the employment competitiveness of professional students, but also produce a good demonstration effect and radiation effect. In addition, in the process of implementing the government purchase reform of college students post practice service, we can continuously expand the school-enterprise cooperative practice base, constantly improve the key indicators such as 
students' professional counterpart rate and post counterpart rate, and significantly enhance students'professional practice ability, professional innovation ability and employment competitiveness.

\section{Acknowledgements}

The stage results of key projects of Chongqing's higher education teaching reform, such as "Innovation and Exploration of College Student post practice Management under the Mode of Government Purchase Service" (approval number 162039: host: Tian Shuqin) and "Development and Practice of College post practice Management Integrated System under the Age of Big Data"(approval number No. 162040: host: Wang Daping).

\section{References}

[1] The ManagementRegulations on the Students'Practice in Vocational Schools by the Ministry of Education and other five departments $[\mathrm{EB} / \mathrm{OL}]$. Department of vocational education and adult education, Ministry of $\quad$ Education[2016] No. http://www.moe.edu.cn/srcsite/A07/moe_950/201604/t20160426_240252.html.

[2] Yang Bao. Comparison and Interpretation of Government Purchase Service Models - A Study of Institutional Transition [J].China Administration, 309 (3)(2013) 41-45.

[3] Wang Dongqiang, Tang Longjia.The management mechanism for post practice of Normal University Students based HRM [J].Journal of Tangshan Teachers College, 35 (3)(2013) 128-132.

[4]JIN Zelong.The Internship of University-enterprise Cooperation Project under the Perspective of Enterprise[J].Chongqing Higher Education R esearch,2 (4)(2014) 73-77.

[5] Chen Chuanqi. The study on vocational education students' practice service system of Government Purchase [D]. Southwest University of Political Science and Law(2016)

[6] Li Jizhong, Xue Yanping.Design of Post Practice Teaching Project in Higher Vocational College[J].Journal of Hebei Normal University (Educational Science Edition), 17(01)(2015)134-138. 